\title{
Adsorption of Toxic Ni (II) from an Aqueous Solution by Bentonite
}

\author{
Soad Mohamed Sallam ${ }^{1}$, Abeer El-Saharty ${ }^{2, ~}$, Abdel-Moniem Ahmed ${ }^{1}$ \\ ${ }^{1}$ Chemistry Department, Faculty of Science, Alexandria University, Alexandria, Egypt \\ ${ }^{2}$ National Institute of Oceanography and Fishers, Alexandria, Egypt
}

Email address:

saharty@yahoo.com (A. El-Saharty)

${ }^{*}$ Corresponding author

\section{To cite this article:}

Soad Mmohamed Sallam, Abeer El-Saharty, Abdel-Moniem Ahmed. Adsorption of Toxic Ni (II) from an Aqueous Solution by Bentonite. International Journal of Ecotoxicology and Ecobiology. Vol. 2, No. 4, 2017, pp. 158-165. doi: 10.11648/j.ijee.20170204.14

Received: August 16, 2017; Accepted: August 28, 2017; Published: November 30, 2017

\begin{abstract}
In this study, the adsorption potential of bentonite for removal of $\mathrm{Ni}(\mathrm{II})$ ions from wastewater has been investigated. The study involves batch type experiments to investigate the effect of initial concentration, adsorbent dose, agitation speed, contact time, temperature and $\mathrm{pH}$ of the solution on adsorption process and the optimum conditions were evaluated. The adsorption process fits pseudo-second order kinetic models. Langmuir and Freundich adsorption isotherm models were applied to analyze adsorption data and both were found to be applicable to the adsorption process. Thermodynamic parameters, e.g., $\Delta \mathrm{G}^{\mathrm{o}}, \Delta \mathrm{S}^{\mathrm{o}}$ and $\Delta \mathrm{H}^{\mathrm{o}}$ of the on-going adsorption process have also been calculated and the sorption process was found to be endothermic. Finally, it can be seen that Bentonite was found to be more effective for the removal of $\mathrm{Ni}(\mathrm{II})$ at the same experimental conditions.
\end{abstract}

Keywords: Waste Water, Nickel, Bentonite, Adsorption

\section{Introduction}

Water contamination by heavy metals in industrial effluents is a serious environmental problem. This situation has led to development of research aiming at its reduction or elimination and at the appreciation of residues obtained through physical, chemical, thermal, biological or mixed treatments.

Among heavy metals, nickel is one of the most utilizedelementsin the manufacturing process of stainless steel, super alloys, metallic alloys, coins, batteries etc. Direct exposition to nickel causes dermatitis. Some nickel compounds, such as carbonyls, are carcinogenic and easily absorbed by skin. The exposure to this compound at an atmospheric concentration of $30 \mathrm{ppm}$ for half an hour is lethal [1].

The existing literature reports many studies on the removal of heavy metals from water and effluents, including chemical precipitation, physical treatment such as ion exchange, solvents extraction and adsorption, However, considering the high costs for the maintenance andthe importation of chemical products or conventional adsorption, some methods have become unsustainable.

Several studies have demonstrated that the selectivity and the efficiency in the removal of pollution agents, such as heavy metals from effluents through an adsorption process, depend greatly on physical properties and chemical composition of the adsorbents.

Recently, the use of clay for sorptionor elimination of heavy metals in effluents has been conisderd as an object of study in a great deal of research due to its several economic advantages [2-4]. The cost of these adsorbents is relatively low when it's compared to other alternative adsorbents, including activated coal, natural and synthetic zeolites, ionexchange resins and other adsorbent materials.

Clay and minerals as montmorillonite, vermiculite, illite, caulinite and bentonite are some natural materials that are being studied as heavy metals adsorbents [5-6]. Another advantage of using clay as an adsorbent is related to its intrinsic properties such as: great specific surface area, 
excellent physical and chemical stability and several other structural and surface properties [7].

The acceptable limit of $\mathrm{Ni}$ in drinking water is $0.01 \mathrm{mg}$ ${ }^{1}$ and for the discharge of industrial water is $2.0 \mathrm{mgL}^{-1}$. At higher concentrations, Ni(II) causes cancer of lungs, nose and bone. Dermatitis $\mathrm{Ni}$ itchis the most frequent effect of exposure to $\mathrm{Ni}$, such as coins and costume jewels. $\mathrm{Ni}$ carbonyl $\left[\mathrm{Ni}(\mathrm{CO})_{4}\right]$ has been estimated as lethal in humans at atmospheric exposures of $30 \mathrm{ppm}$ for $30 \mathrm{~min}$ [8]. Acute poisoning of $\mathrm{Ni}(\mathrm{II})$ causes headache, dizziness, nausea and vomiting, chest pain, tightness of the chest, dry cough and shortness of breath, rapid respiration, cyanosis and extreme weakness.

Hence, it is essential to remove $\mathrm{Ni}$ (II) from industrial waste water before mixing with natural waste sources. In advanced countries, removal of $\mathrm{Ni}$ (II) metal ions in waste water is normally achieved by advanced technologies such as precipitation-filtration, ion exchange and membrane separation [9]. However, in developing countries, these treatment can 't be applied because of the technical levels and insufficient funds. Therefore, it is desired to simple and economical removal methods which can utilized in developing countries. Although the treatment cost for precipitation- filtration method is comparatively cheap, the treatment procedure is complicated. On the other hand, adsorption method such as ion exchange and membrane separation is simple one for the removal of heavy metals. However, there is a limit in the generality in developing countries because chelating and ion-exchange resins are expensive. In the present study, removal of Ni(II) ions from wastewater was further carried out by adsorption onto bentonite.

The objectives of the present study are: 1) studying the effect of contact time on $\mathrm{Ni}^{+2}$ ions adsorption onto Bentonite; 2) to investigate the influence of $\mathrm{PH}$ on the adsorption of $\mathrm{Ni}^{+2}$ ions;3)to study the adsorption of $\mathrm{Ni}^{+2}$ ions at different temperatures and to calculate the adsorption thermodynamic parameters (i.e., $\Delta \mathrm{H}^{0}, \Delta \mathrm{S}^{0}, \Delta \mathrm{G}^{0}$; 4) to find the effect of adsorbent dose and the initial concentration on the adsorption of $\mathrm{Ni}^{+2}$ ions;5)to describe the experimental data of adsorption isotherm through Langmuir and freundlich models; 6) to discuss the adsorption mechanism of $\mathrm{Ni}^{+2}$ ions onto both adsorbents.

\section{Experimental}

\subsection{Materials and Reagents}

All chemicals used in the present work were either of analytical reagent (AR) or laboratory reagents (LR) grade and were used just they have received. Nickel chloride supplied by BDH chemicals Ltd. Distilled water was used in all preparations. Nickel chloride and deionized water were used to prepare synthetic $\mathrm{Ni}^{+2}$ containing waste water.

Powder bentonite produced from natural origin by ADWIC was used as adsorbent as well as American Wyoming used in Alexandria Company for refractories.
Powder Bentonitewas supplied from ADWIC and Alexandria Company for refractories, respectively. The surface area and particle size for the adsorbent were checked Table (1).

Table 1. The surface area and particle size analysis of bentonite.

\begin{tabular}{lll}
\hline Adsorbentsanalysis & Bentonite & \\
\hline Surface area (BET) Nova & II9.8 $\mathrm{m}^{2} / \mathrm{g}$ (dry) & \\
2000Quanta chrome & Size (micrometer) & $\mathrm{Wt} \%$ \\
& $>63$ & 1 \\
& $63-32$ & 1 \\
& $32-16$ & 2 \\
Particle size (XRD) Philips PW & $16-8$ & 3 \\
1730 & $8-4$ & 2 \\
& $4-2$ & 4 \\
& $<2$ & 87 \\
\hline
\end{tabular}

\subsection{Apparatus and Instrumentation}

Magnetic hot plate stirrer was used to stir the solutions of heavy metals ions with adsorbents (bentonite). A definite volume of heavy metal ions solution with a known initial ions concentration was stirred with a definite amount of adsorbents for a certain time at fixed temperature and agitation rate. The $\mathrm{pH}$ values of the solution were measured by digital $\mathrm{pH}$ meter (Model $\mathrm{g} \mathrm{pH}$ system-361, India). The metal ions concentrations were measured by using atomicabsorption spectrophotometer, AAS, (Model, AA55; Varian Inc., USA).

\subsection{Experimental Procedures}

Nickel (II) chloride $\left(\mathrm{NiCl}_{2} \cdot 6 \mathrm{H}_{2} \mathrm{O}\right)$, and redistilled water were used to prepare stock solutions with a concentration of $1000 \mathrm{ppm}$ of the $\mathrm{Ni}(\mathrm{II})$ which was diluted for preparation of test solutions. Several solutions with different initial concentrations of nickel chloride (50, 100, 200, 300 and 400 ppm) were prepared. Adjustment of $\mathrm{pH}$ was carried out by using $0.1 \mathrm{~N} \mathrm{NaOH}$ and or $0.1 \mathrm{~N} \mathrm{HCI}$. All experiments conditions were optimized to achieve maximum removal efficiency (RE) for all heavy metals ions by adding different amounts of both adsorbent $(0.1,0.3,0.5,0.7$ and $1.0 \mathrm{~g})$ to different concentrations of $250 \mathrm{~mL}$ of heavy metal ions solution. The agitation rate for all experiments was $200 \mathrm{rpm}$ and the residence time was $(0,15,30,45,60,75,90$ and 120 $\min )$ at $25^{\circ} \mathrm{C}$.

$1 \mathrm{~mL}$ of Sample was taken from each reaction solution and diluted to $10 \mathrm{~mL}$ by redistilled water, adsorbents were then separated from the solution by using filter paper (Watman No. 40) and the residual $\mathrm{Ni}(\mathrm{II})$ ions concentrations in the each solution was then determined by atomic- absorption spectrophotometer (AAS). The effects of several parameters, such as contact time, initial concentration, adsorbent dose, $\mathrm{pH}$ value and temperature on the adsorption of $\mathrm{Ni}$ (II) ions onto bentonite were studied.

\subsection{Data Analysis}

The uptake of $\mathrm{Ni}(\mathrm{II})$ ions were calculated by the mass 
balance, which was stated as the amount of solute adsorbed onto the solid. It equals the amount of solute removed from the solution. Mathematically, it can be expressed by Eq. (1):

$$
\mathrm{q}_{\mathrm{e}}=\left(\mathrm{C}_{\mathrm{i}}-\mathrm{C}_{\mathrm{e}}\right) / \mathrm{S}
$$

Where

$\mathrm{q}_{\mathrm{e}}$ is the heavy metal ions concentration adsorbed by an adsorbent at equilibrium

(mg of metal ions/g of adsorbent)

$\mathrm{C}_{\mathrm{i}}$ is the initial concentration of metal ions in the solution $(\mathrm{mg} / \mathrm{l})$

$\mathrm{C}_{\mathrm{e}}$ is the equilibrium concentration or final concentration of metal ions in the solution $(\mathrm{mg} / \mathrm{l})$

Sis the dosage concentration and it is expressed by Eq. (2):

$$
\mathrm{S}=\mathrm{m} / \mathrm{V}
$$

Where $\mathrm{V}$ is the initial volume of metal ions solution used (L) andm is the weight of driedadsorbent (g) used. (3):

The percentage of adsorption (\%) is calculated using Eq.

$$
\% \text { adsorption }=\left[\left(\mathrm{C}_{\mathrm{i}}-\mathrm{C}_{\mathrm{e}}\right) / \mathrm{C}_{\mathrm{i}}\right] * 100
$$

\section{Adsorption kinetic's}

To investigate the mechanism of nickel (II) ions adsorption onto bentonite, two kinetics models were considered as follows:

Largergren pseudo-first order model can be expressed by Eqs. (4) and (5):

$$
\begin{array}{r}
\mathrm{dq} / \mathrm{dt}=\mathrm{k}_{\mathrm{l}}\left(\mathrm{q}_{\mathrm{e}}-\mathrm{q}\right) \\
\ln \left(\mathrm{q}_{\mathrm{e}}-\mathrm{q}\right)=\operatorname{In} \mathrm{q}_{\mathrm{e}}-\mathrm{k}_{\mathrm{l}} \mathrm{t}
\end{array}
$$

The pseudo-second order model is given by Eqs. (6) and (7):

$$
\begin{aligned}
\mathrm{dq} / \mathrm{dt} & =\mathrm{k}_{2}\left(\mathrm{q}_{\mathrm{e}}-\mathrm{q}\right)^{2} \\
\mathrm{t} / \mathrm{q} & =\mathrm{t} / \mathrm{q}_{\mathrm{e}}+1 / \mathrm{k}_{2} \mathrm{q}_{\mathrm{e}}{ }^{2}
\end{aligned}
$$

Where $\mathrm{q}$ and $\mathrm{q}_{\mathrm{e}}$ are the amount of $\mathrm{Ni}^{+2}$ metal adsorbed per unit weight of adsorbent $(\mathrm{mg} / \mathrm{g})$ at time $\mathrm{t}$ and at equilibrium, respectively, and $\mathrm{k}_{1}$ and $\mathrm{k}_{2}$ are the adsorption rate constant. The applicability of the above two models can be examined by each linear plot of $\operatorname{In}\left(\mathrm{q}_{\mathrm{e}}-\mathrm{q}\right) \mathrm{vs}$. $\mathrm{t}$, and(t/q)vs. $\mathrm{t}$, respectively and are represented in Figure (1) and (2). The kinetics study for the adsorption of $\mathrm{Ni}^{+2}$ was conducted at optimum $\mathrm{pH} 5.0$ and completed in $2 \mathrm{~h}$ for the concentrations (50, 100, and 200 $\mathrm{mg} / \mathrm{l})$ of $\mathrm{Ni}^{+2}$ ions onto $(0.1,0.3,0.5,0.7$, and $1.0 \mathrm{~g} / 250 \mathrm{~mL})$ doses of adsorbents at $25^{\circ} \mathrm{C}$. The validity of the kinetics models is tested by the magnitude of the regression coefficient $\mathrm{R}^{2}$, given in Table (1). It is important to note that for pseudo-first order, the correlation coefficient is always less than 0.98, which is indicative of less significant correlation. In contrast, the application of pseudo-second order model leads to much better regression coefficient, all greater than 0.99. moreover, from Table (1) and Figure (1) and (2), the qe, the values estimated from the pseudo-first kinetic model gave significantly were also found to be lower. However, in pseudo-second order kinetic model the calculated qe, the values are very close to qe, exp values at various initial concentrations and various adsorbent doses.

For the pseudo-second order kinetics model, the rate constant decrease with increasing of initial Ni(II) concentration.
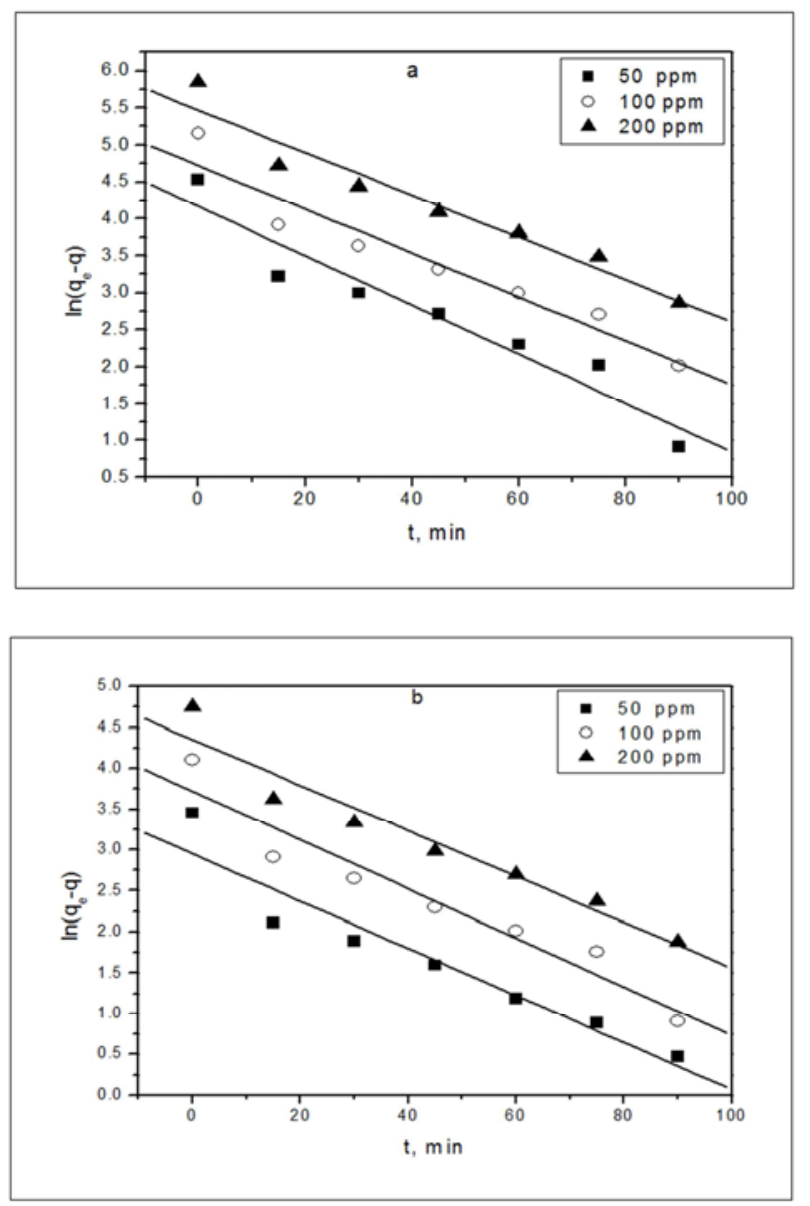

Figure 1. Pseudo-first order kinetic plots for the adsorption of different initial concentrations: 50,100 and $200 \mathrm{ppm} \mathrm{Ni}^{2+}$ ions onto different doses of bentonite:a) $0.1 \mathrm{~g} / 250 \mathrm{~mL}$ and b) $0.3 \mathrm{~g} / 250 \mathrm{~mL}$, (pH: 5.0; agitation speed: 200 rpm; temperature: $25^{\circ} \mathrm{C}$.

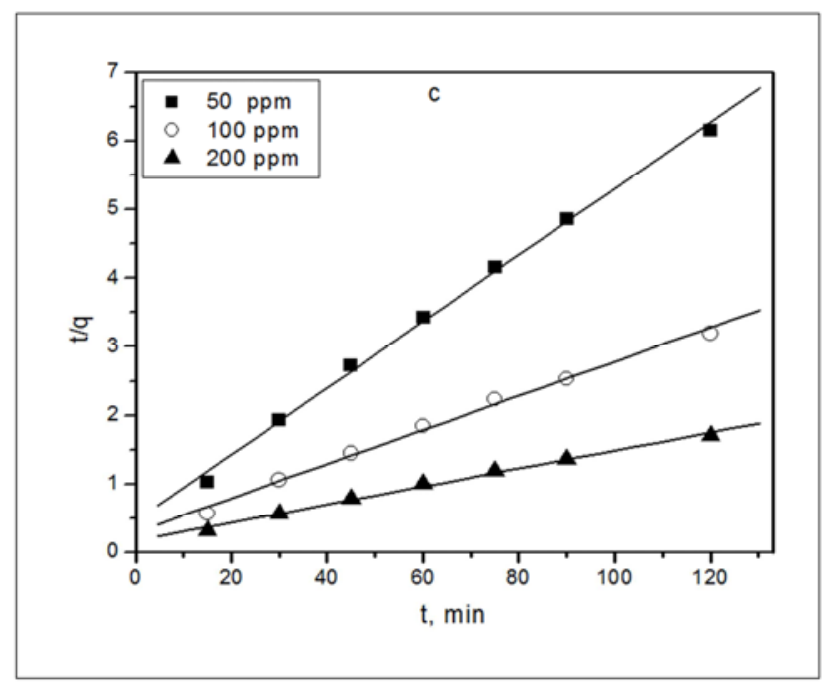




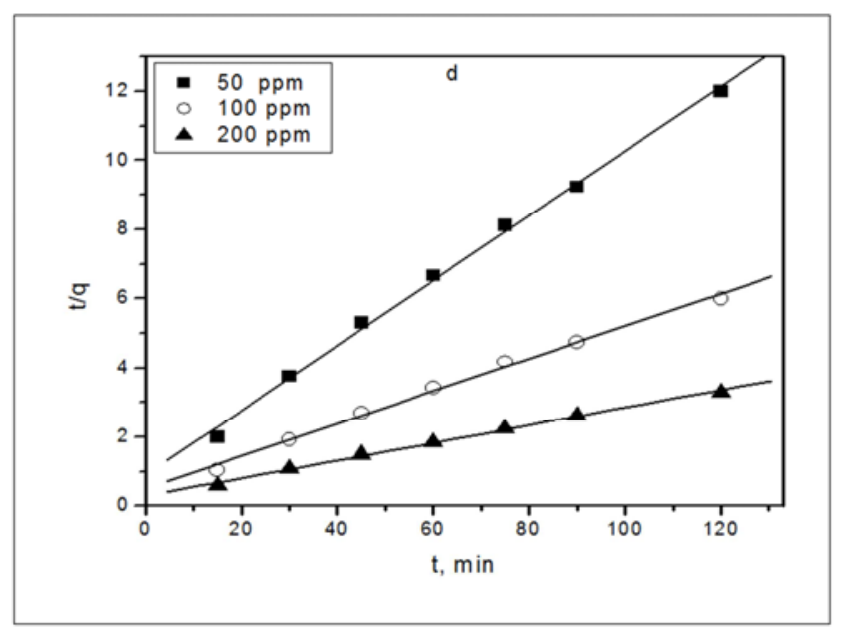

Figure 2. Pseudo-second order kinetic plots for the adsorption of different initial concentrations: 50, 100 and $200 \mathrm{ppm} \mathrm{Ni}^{2+}$ ions onto differentadsorbent doses of bentonite:c) $0.5 \mathrm{~g} / 250 \mathrm{~mL}$ and d) $1.0 \mathrm{~g} / 250 \mathrm{~mL}$, (pH: 5.0; agitation speed: 200 rpm; temperature: $25^{\circ} \mathrm{C}$ ).

\subsection{Effect of Contact Time}

The effect of contact time for five different concentrations of $\mathrm{Ni}^{+2}(50,100,200,300$ and $400 \mathrm{mg} / \mathrm{l})$ onto $(0.1,0.3,0.5$, 0.7 and $1.0 \mathrm{~g} / 250 \mathrm{~mL}$ ) of Bentonite doses, $\mathrm{pH} 5.0$ at $25^{\circ} \mathrm{C}$ is shown in

Figure (3). Thenickel (II) percentage removalinc-reased by time until the equilibrium is attained between the amounts of nickel (II) adsorbed onto both adsorbents and the remaining solution. The figure shows that the adsorption of $\mathrm{Ni}^{+2}$ increase with the time from 0 to $30 \mathrm{~min}$ and more and then increased slowly up to the end of experiment. It can be concluded that the rate of the $\mathrm{Ni}$ (II) binding with bentonitewasmore at initial stages, which gradually decrease and becomes almost constant after an optimum period of 90 $\min$.

Figure (4) shows the relation between the amount of adsorbed ions per gram of adsorbent and contact time in the presence of different amounts of adsorbents at $25^{\circ} \mathrm{C}$. At the beginq raises rapidly and by time it increases slowly till he maximum adsorption.

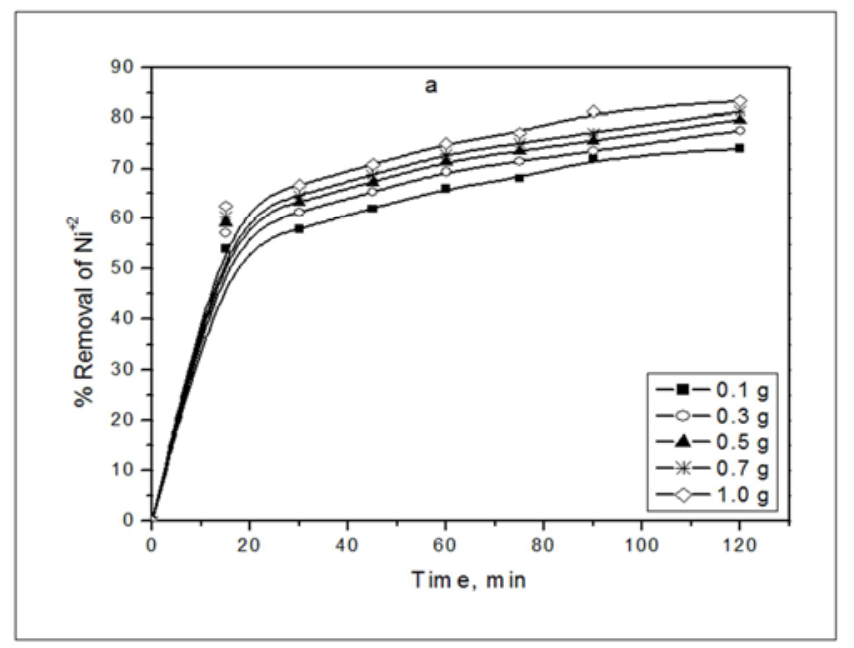

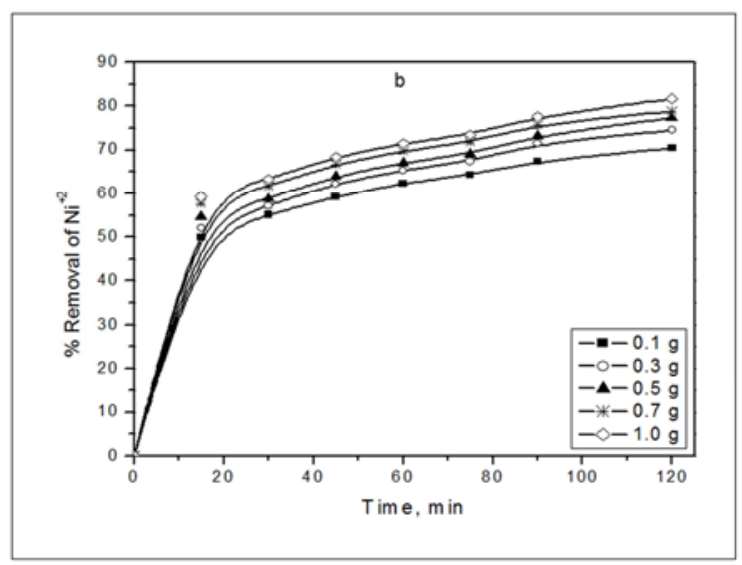

Figure 3. Effect of contact time (min) on \% removal of $\mathrm{Ni}^{2+}$ ions for: a) 50 ppm and b) $100 \mathrm{ppm}$, in the presence of different amounts of bentonite (temp. $=25^{\circ} \mathrm{C}, \mathrm{pH}=5.0$ and equilibrium time $=2 \mathrm{~h}$ ).
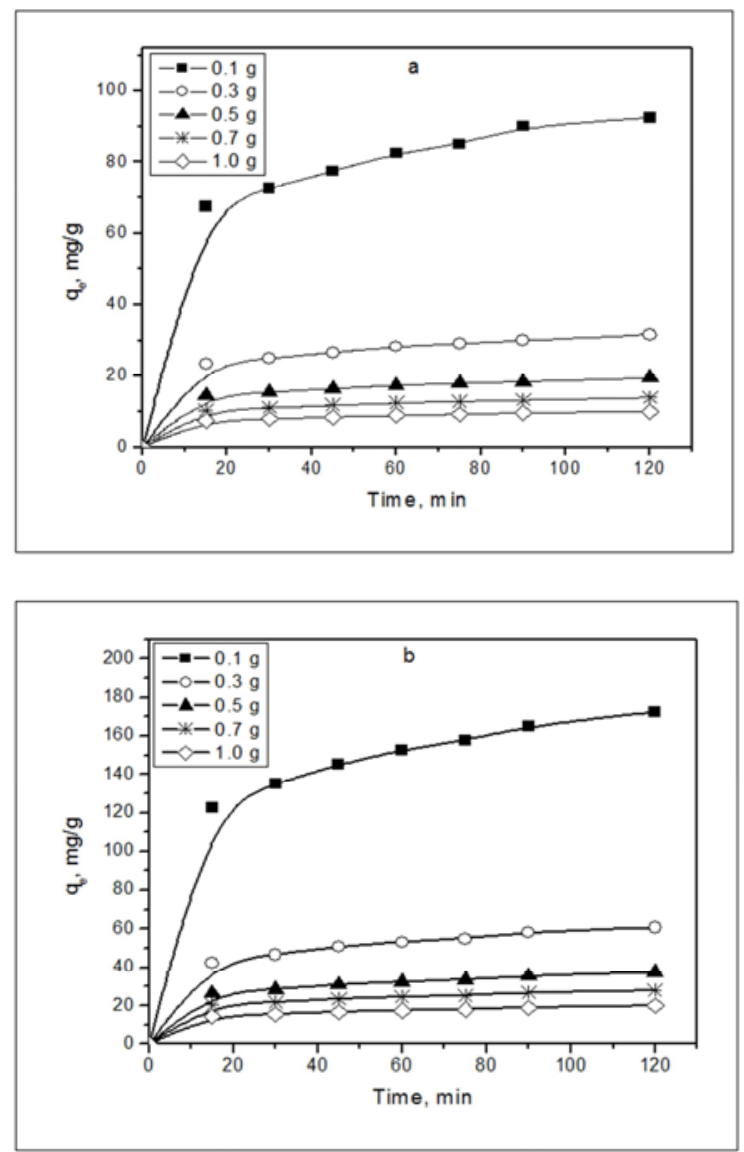

Figure 4. Effect of contact time on adsorbed amount of $\mathrm{Ni}^{2+}$ for different concentrations: a) $50 \mathrm{ppm}$, b) $100 \mathrm{ppm}$, in the presence of different amounts of bentonite (temp. $=25^{\circ} \mathrm{C}, \mathrm{pH}=5.0$ and equilibrium time $=2 \mathrm{~h}$ ).

\subsection{The Effect of Adsorbent Dose}

The effect of adsorbent dose on percentage removal of (50, $100,200,300$ and $400 \mathrm{mg} / \mathrm{L}$ ) $\mathrm{Ni}$ (II) ions concentrations at $25^{\circ} \mathrm{C}$ are shown in Figure (5). Percentage of nickel (II) ions removal/ increased when the adsorbent dose increased from 0.1 to $1.0 \mathrm{~g} 1250 \mathrm{~mL}$ for bentonite. It can be seen that, the number of adsorption sites or surface area increases with the weight of adsorbent and hence results in a higher percent of 
metal ions removal at a high dose. However, the amount of metal ions adsorbed per unit weight of adsorbent (q) decreases with the adsorbent dose. This is due to the fact that at higher adsorbent dose the solutions ion concentration drops to a lower value and the system reaches equilibrium at lower values of $\mathrm{q}$ indicating the adsorption sites remain unsaturated.

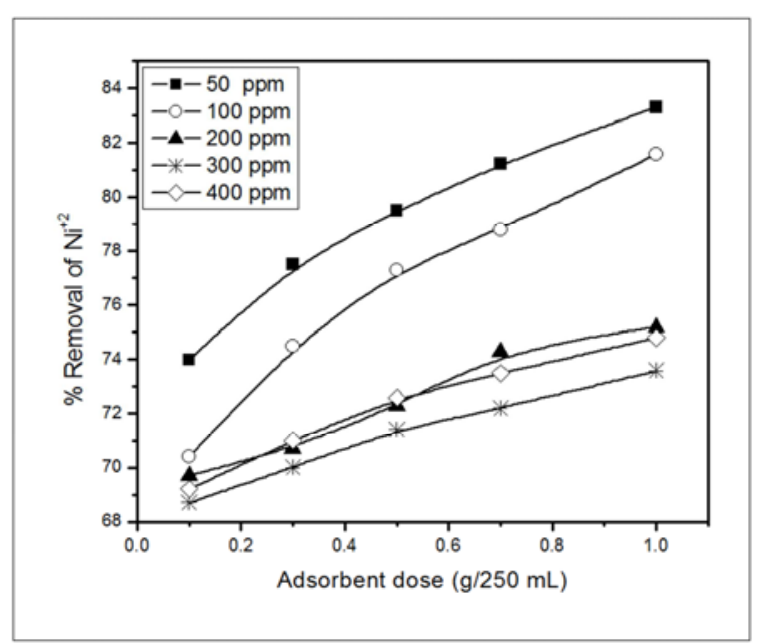

Figure 5. The effect of variant bentonite adsorbent doses (0.1, 0.3, 0.5, 0.7 and $1.0 \mathrm{~g} / 250 \mathrm{ml}$ ) on \% removal for different $\mathrm{Ni}^{2+}$ ions initial concentrations solutions at $25^{\circ} \mathrm{C}$.

\subsection{Effect of Initial Nickel (II) Ions Concentration}

An increase of initial $\mathrm{Ni}(\mathrm{II})$ concentration from 50 to 300 $\mathrm{mg} / \mathrm{L}$ with different amounts of bentonite $(0.1,0.3,0.5,0.7$ and $1.0 \mathrm{~g} / 250 \mathrm{~mL}$ ) when other experimental conditions are kept constant, illustrated in Figure (6) It can be seen from the figures that, \% removal of $\mathrm{Ni}(\mathrm{II})$ increases when the initial concentration decreased. At low ions concentrations the ratio of surface active sites to the total metal ions in the solution is high and hence all metal ions may interact with the adsorbent and be removed from the solution. However, the amount of metal adsorbed per unit weight of adsorbent, q, is higher at high concentration.

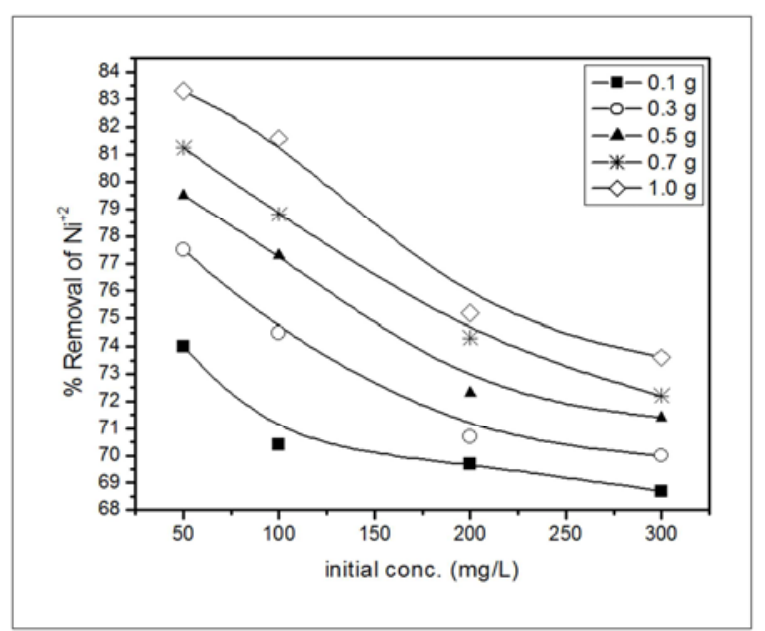

Figure 6. The effect of initial concentration (namely 50, 100, 200 and 300 $\mathrm{mg} / \mathrm{L}$ ) on \% removalof $\mathrm{Ni}^{2+}$ ions in the presence of different amounts of bentonite (temp. $=25^{\circ} \mathrm{C}, \mathrm{pH}=5.0$ and equilibrium time $=2 \mathrm{~h}$ ).

\subsection{Effect of $\mathrm{pH}$ on the Uptake of $\mathrm{Ni}^{+2}$}

The $\mathrm{pH}$ value of the solution is an important controlling parameter in the adsorption process, and the initial $\mathrm{pH}$ value of the solution has more influence than the final $\mathrm{p} 1$ I, which influences both the adsorbent surface metal binding sites and the metal chemistry in water. Hence, the influence of $\mathrm{pH}$ on the adsorption of $\mathrm{Ni}$ (II) onto Bentonite was examined in the range of $2-9 \%$; the results are shown in Figure (7)

This figure shows that, the sorption of Ni(II) increases with increasing $\mathrm{pH}$ at $\mathrm{pH} 2-7$, then decreases with increasing $\mathrm{pH}$ at $\mathrm{pH}>7$ and at last maintains a low level at $\mathrm{pH}>8.5$. The abrupt increase of $\mathrm{Ni}$ (II) sorption may be attributed to the surface precipitation of $\mathrm{Ni}(\mathrm{OH})_{2}(\mathrm{~S})$ onto bentonite.

It is well known that $\mathrm{Ni}$ (II) can be easily form precipitated because of the low solubility of $\mathrm{Ni}(\mathrm{OH})_{2}$. It is clear that $\mathrm{Ni}$ (II) ions start to form precipitation at $\mathrm{pH} \sim 6$. However, one can see that more than $90 \% \mathrm{Ni}$ (II) has been adsorbed to bentonite at $\mathrm{pH}>5$.

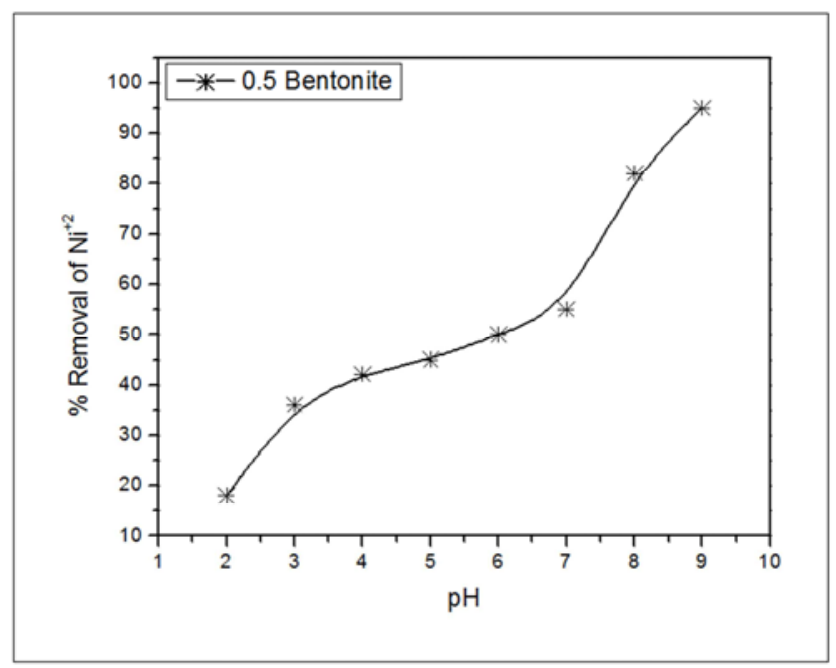

Figure 7. Effect of $\mathrm{pH}$ for the adsorption of $\mathrm{Ni}^{2+}$ ions onto bentonite (conditions; $\mathrm{Ni}^{2+}$ ions initial concentration: $100 \mathrm{mg} / \mathrm{L}$; adsorbent dose: 0.5 $\mathrm{g} / 250 \mathrm{~mL}$; agitation speed:200 rpm; contact time: $2 \mathrm{~h}$ ) at $25^{\circ} \mathrm{C}$.

\subsection{Effect of Temperature}

The effect of temperature on the efficiency of adsorption of $\mathrm{Ni}$ (II) was studied at different temperature in the range of $25-40^{\circ} \mathrm{C}$. The adsorption experiments were carried out with $(50,100,200,300$ and $400 \mathrm{mg} / \mathrm{L})$ initial concentrations of $\mathrm{Ni}$ (II) onto $0.5 \mathrm{~g} / 250 \mathrm{~mL}$ for bentonite at $\mathrm{pH}$ 5.0. The adsorption of $\mathrm{Ni}^{+2}$ onto the adsorbent increase by increasing temperature from 25 to $40^{\circ} \mathrm{C}$. Figure (8) indicates that the $\mathrm{Ni}(\mathrm{II})$ uptake by adsorption onto bentonite and bentonitefavours at higher temperature. This may be due to availability of more active sites of both adsorbent at higher temperature. 


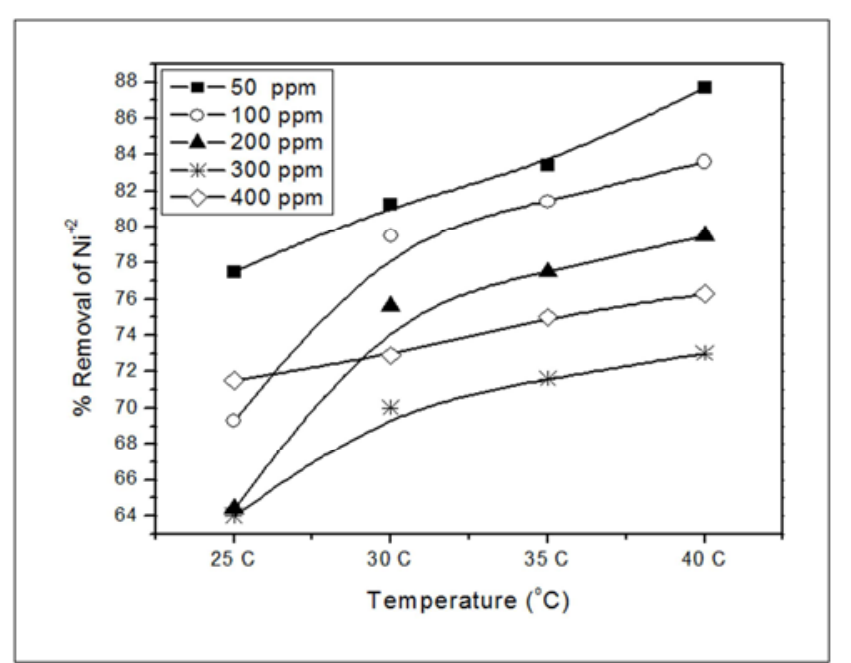

Figure 8. The effect of temperature between 25 and $40^{\circ} \mathrm{C}$ for the \% removal of different initial $\mathrm{Ni}^{2+}$ ions concentrations onto bentonite (conditions; $\mathrm{pH}$ : 5.0; adsorbents dose: $0.5 \mathrm{~g} / 250 \mathrm{~mL}$; agitation speed: $200 \mathrm{rpm}$; contact time: $2 \mathrm{~h}$ ).

\subsection{Adsorption Isotherm}

Adsorption isotherm is an expression that shows the relationship between amounts of adsorbate adsorbed per unit weight of adsorbent (qe, $\mathrm{mg} / \mathrm{g}$ ) and the concentration of adsorbate in bulk solution $(\mathrm{Ce}, \mathrm{mg} / \mathrm{L})$ at given temperature under equilibrium conditions. Adsorption equilibrium is established when the amount of adsorbate being adsorbed is equal to the amount being desorbed from the adsorbent. At this stage, the equilibrium concentrations in both phases are constant. Adsorption isotherm is very useful in giving information about adsorption mechanisms, surface properties and affinity of an adsorbent towards heavy metals ions [10, 11]. The isotherm data were further analyzed with two most common isotherm models.

The Langmuir and freundlich models (Langmuir, 1916; freundlich, 1906), are the most frequently employed to describe equilibrium for the adsorption of $(50,100$, and 200 $\mathrm{mg} / \mathrm{L}) \mathrm{Ni}^{+2}$ ions concentrations onto $(0.1,0.3,0.5,0.7$ and $1.0 \mathrm{~g} / 250 \mathrm{~mL}$ ) of bentonite doses, $\mathrm{pH} 5.0$ at $25^{\circ} \mathrm{C}$. The Langmuir isotherm is probably the most widely applied isotherm model in many adsorption studies. The developed model was based on assumptions that adsorption occurs at specific homogenous sites on the adsorbent and was used successfully in many monolayer, adsorption processes. It also assumes no transmigration of adsorbate in the plane of adsorbent surface.

The Langmuir isotherm for adsorption can be obtained from Eq. (8):

$$
\mathrm{C}_{\mathrm{e}} / \mathrm{q}_{\mathrm{e}}=1 /\left(\mathrm{q}_{\max } \mathrm{b}\right)+\left(\mathrm{l} / \mathrm{q}_{\max }\right) \mathrm{C}_{\mathrm{e}}
$$

Where $\mathrm{q}_{\max }$ is the maximum metal ions uptake per unit mass of adsorbent $(\mathrm{mg} / \mathrm{g})$, which is related to the adsorption capacity and $b$ is Langmuir constant $(\mathrm{L} / \mathrm{mol})$ which is exponentially proportional to the heat of adsorption and related to the adsorption intensity. Therefore, a plot of $\mathrm{C}_{\mathrm{e}} / \mathrm{q}_{\mathrm{e}}$ versus $\mathrm{C}_{\mathrm{e}}$ gives a straight line of the slop $1 / \mathrm{q}_{\max }$ and intercept $1 /\left(\mathrm{q}_{\max } \mathrm{b}\right)$ as shown in Figure (9)

Freundlich isotherm gives the relationship between equilibrium liquid and solid phase capacity based on the multilayer adsorption (heterogeneous surface). This isotherm is derived from the assumption that the adsorption sites are distributed exponentially with respect to the heat of adsorption. It also assumes that the stronger adsorption sites are occupied first and the binding strength decreases with the increasing degree of site occupation. The Freundlich model is given by (Freundlich, 1906) the classical empirical isotherm, Eq. (9):

$$
\mathrm{Inq}_{\mathrm{e}}=\mathrm{InK}_{\mathrm{F}}+1 / \mathrm{n} \mathrm{InC} \mathrm{C}_{\mathrm{e}}
$$

The Freundlich adsorption isotherm is an indicator of the extent of heterogeneity of the adsorbent surface, where the Freundlich constants $\mathrm{K}_{\mathrm{F}}$ and $\mathrm{n}$, which respectively indicating the adsorption capacity and the adsorption intensity, were calculated from the intercept and slope of the plot of $\mathrm{Inq}_{\mathrm{e}}$ versus $\mathrm{InC}_{\mathrm{e}}$ as shown in Figure (10)

This Freundlich type behavior is indicative of surface heterogeneity of the adsorbents, i.e. the adsorptive sites (surface of bentonite) are made up of small heterogeneous adsorption patches that are homogenous in themselves. The activation of adsorption sites takes place, leading to increased adsorption probably through the surface exchange mechanism.

The calculated results of Langmuir and frendlich isotherm constants are given in Table (2). It can be seen that, the Freundich model yields a much better fit than the Langmuir model, when the correlation coefficient $\left(\mathrm{R}^{2}\right)$ values are compared in Table (3) $\left(\mathrm{R}^{2}\right.$ values of Freundich plot $>0.99$ was closed to unity, indicating isotherm data fitted well to Freundich model). The Freundich constant $\left(\mathrm{K}_{\mathrm{F}}\right)$ indicates the sorption capacity of the sorbent. From Table (3), it is noticed that the values of (n) are bigger than 1, reflecting the favorable adsorption.

The plots of $\mathrm{q}_{\mathrm{e}}$ versus $\mathrm{Ce}$ are presented in Figure (9) and (10), it is seen that qe increased by increasing Ce with higher slope at the initial stages which indicates that, initially, there are numerous readily accessible sites for adsorption process. Eventually qe reaches maximum value at higher $\mathrm{Ce}$, indicating that the adsorption is saturated at this level.

\begin{tabular}{|c|c|c|c|c|c|c|c|c|}
\hline \multirow{2}{*}{ Adsorbent } & \multirow{2}{*}{$\begin{array}{l}\mathrm{C}_{0} \\
(\mathrm{mg} / \mathrm{L})\end{array}$} & \multirow{2}{*}{$q_{\mathrm{e} \text { exp. }}(\mathrm{mg} / \mathrm{g})$} & \multicolumn{3}{|c|}{ Lagergren first order } & \multicolumn{3}{|c|}{ Pseudo-second order } \\
\hline & & & $K_{1}\left(\min ^{-1}\right)$ & $q_{1, \text { theo. }}(\mathrm{mg} / \mathrm{g})$ & $\mathbf{R}^{2}$ & $\mathrm{k}_{2}\left(\mathrm{gmg}^{-1} \mathrm{~min}^{-1}\right)$ & $q_{2, \text { theo. }}(\mathrm{mg} / \mathrm{g})$ & $\mathbf{R}^{2}$ \\
\hline \multirow{3}{*}{$\begin{array}{l}\text { Bentonite } \\
(0.1 \mathrm{~g})\end{array}$} & 50 & 92.5 & $3.8 \times 10^{-2}$ & 64 & 0.923 & $9.5 \times 10^{-4}$ & 92 & 0.993 \\
\hline & 100 & 172.5 & $2.9 \times 10^{-2}$ & 112 & 0.931 & $5.1 \times 10^{-4}$ & 174 & 0.996 \\
\hline & 200 & 345 & $2.8 \times 10^{-2}$ & 237 & 0.945 & $2.1 \times 10^{-4}$ & 350 & 0.997 \\
\hline \multirow{3}{*}{$\begin{array}{l}\text { Bentonite } \\
(0.5 \mathrm{~g})\end{array}$} & 50 & 20 & $2.8 \times 10-2$ & 12 & 0.910 & $5.0 \times 10-3$ & 21 & 0.998 \\
\hline & 100 & 38 & $2.7 \times 10-2$ & 24 & 0.914 & $2.1 \times 10-3$ & 40 & 0.994 \\
\hline & 200 & 71 & $2.6 \times 10-2$ & 47 & 0.930 & $9.9 \times 10-4$ & 72 & 0.990 \\
\hline
\end{tabular}

Table 2. The adsorption kinetics model rate constants for adsorption of $\mathrm{Ni}^{2+}$ ions ontobentonite at various concentrations and constant temperature $25^{\circ} \mathrm{C}$. 


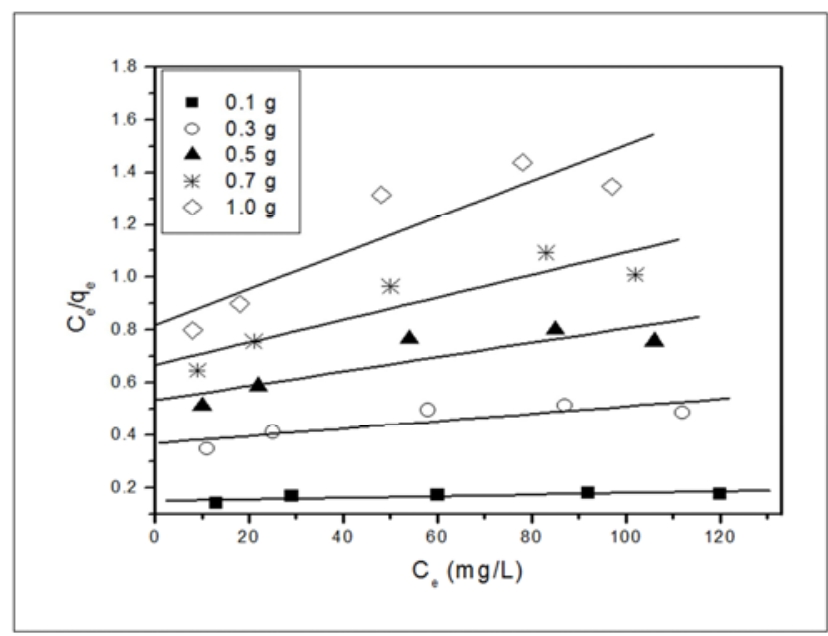

Figure 9. Langmuir adsorption isotherm for $\mathrm{Ni}^{2+}$ ions adsorption onto different amounts of bentonite at constant temperature $25^{\circ} \mathrm{C}$ and contact time $2 \mathrm{~h}$.

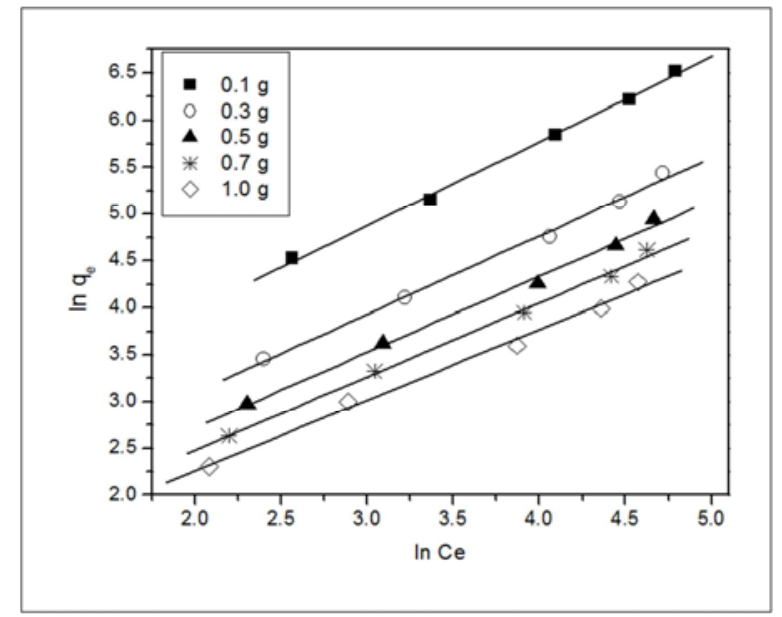

Figure 10. Freundlich adsorption isotherm for $\mathrm{Ni}^{2+}$ ions adsorption onto different amounts of bentonite at constant temperature $25^{\circ} \mathrm{C}$ and contact time $2 h$.

Table 3. Langmuir and Freundlich isotherm for the adsorption of $\mathrm{Ni}^{2+}$ ions onto different doses of bentonite at constant temperature $\left(25^{\circ} \mathrm{C}\right)$.

\begin{tabular}{lllllll}
\hline \multirow{2}{*}{$\begin{array}{l}\text { Adsorbent } \\
\text { (Bentonite) }\end{array}$} & \multicolumn{2}{l}{ Langmuir Isotherm constants } & \multicolumn{3}{l}{ Freundlich Isotherm constants } \\
\cline { 2 - 7 } & $\mathbf{q}_{\max }(\mathbf{m g} / \mathbf{g})$ & $\mathbf{b}(\mathbf{L} / \mathbf{m o l})$ & $\mathbf{R}^{\mathbf{2}}$ & $\mathbf{K}_{\mathbf{F}}(\mathbf{m g} / \mathbf{g})$ & $\mathbf{n}^{\mathbf{2}}$ & 1.118 \\
\hline$(0.1 \mathrm{~g} / 250 \mathrm{~mL})$ & 90 & $3.7 \times 10^{-2}$ & 0.905 & 8.96 & 0.999 \\
$(0.3 \mathrm{~g} / 250 \mathrm{~mL})$ & 96 & $4.2 \times 10^{-3}$ & 0.785 & 4.15 & 1.192 & 0.998 \\
$(0.5 \mathrm{~g} / 250 \mathrm{~mL})$ & 121 & $5.1 \times 10^{-3}$ & 0.882 & 3.11 & 1.236 & 0.997 \\
$(0.7 \mathrm{~g} / 250 \mathrm{~mL})$ & 234 & $6.4 \times 10^{-3}$ & 0.822 & 2.46 & 1.267 & 0.995 \\
$(1 \mathrm{~g} / 250 \mathrm{~mL})$ & 245 & $8.38 \times 10^{-3}$ & 0.815 & 2.34 & 1.325 & 0.995 \\
\hline
\end{tabular}

\section{Thermodynamic parameters}

The determination of thermodynamic parameters has a great importance to evaluate spontaneous and heat change for the adsorption reaction. The apparent equilibrium constant $(\mathrm{Kc})$ of the adsorption is defined as:

$$
\mathrm{K}_{\mathrm{c}}=\mathrm{C}_{\mathrm{Ae}} / \mathrm{Ce}
$$

The standard Gibb`s energy was evaluated by:

$$
\Delta \mathrm{G}^{\circ}=-\mathrm{RT} \operatorname{lnKc}
$$

Where $\mathrm{R}$ is the ideal gas constant $\left(8.314 \mathrm{~J} \mathrm{~mol}^{-\mathrm{I}} \mathrm{K}^{-1}\right)$ and $\mathrm{T}$ is the temperature $(\mathrm{K})$.

Where $\mathrm{C}_{\mathrm{Ae}}$ and $\mathrm{Ce}$ (both in $\mathrm{mg} / \mathrm{L}$ ) are the equilibrium concentrations for $\mathrm{Ni}$ (II) ions onto the sorbent and in the solution, respectively. In this case, the activity should be used instead of concentration in order to obtain the standard thermodynamicequilibrium constant $(\mathrm{Kc})$ of the adsorption system.

\section{$\operatorname{LnKc}=\Delta \mathrm{H}^{\circ} / \mathrm{RT}+\Delta \mathrm{S}^{\circ} / \mathrm{R}$}

The plot of InKc as a function of $1 / \mathrm{T}$ yields a straight line is shown on Figure (11) from which $\Delta \mathrm{H}^{\circ}$ and $\Delta \mathrm{S}^{\circ}$ can be calculated from the slope and intercept, respectively.

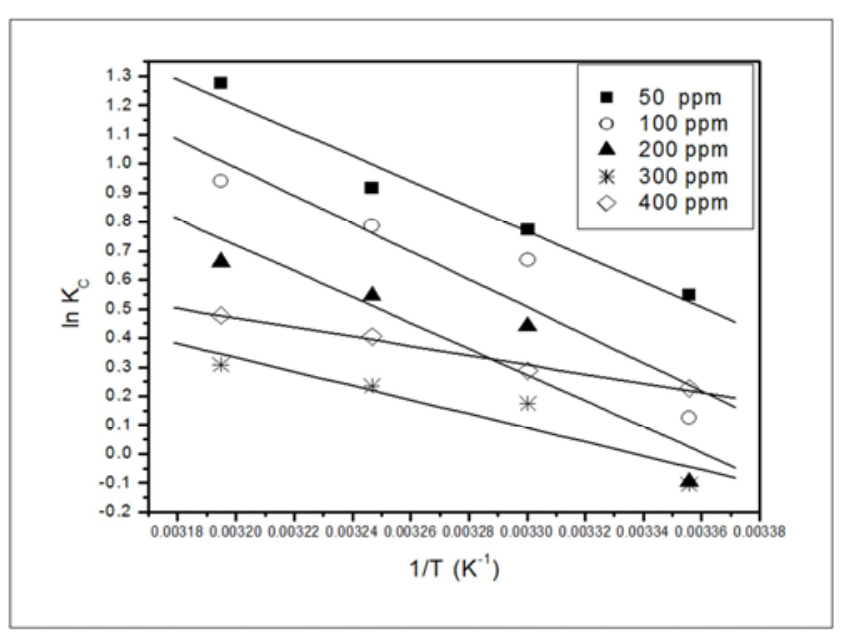

Figure 11. A plot of $\operatorname{lnKc}$ versus $1 / \mathrm{T}$ for $\mathrm{Ni}^{2+}$ ions adsorption onto bentonite for different initial $\mathrm{Ni}^{2+}$ concentrations at constant adsorbent dose: $0.5 \mathrm{~g} / 250 \mathrm{~mL}$.

The negative values of $\Delta \mathrm{G}^{\circ}$ at all temperatures $(25,30,35$ and $40^{\circ} \mathrm{C}$ ) indicate the spontaneous nature of the adsorption of $(50,100,200,300$ and $400 \mathrm{mg} / \mathrm{L})$ of $\mathrm{Ni}$ (II) onto $0.5 \mathrm{~g} / 250$ $\mathrm{mL}$ of Bentonite. The change of the standard free energy decreases with increasing temperatures regardless of the nature of adsorbent. This indicates that a better adsorption is actually obtained at higher temperature. It has been reported that, $\Delta \mathrm{G}^{\circ}$ values up to $-20 \mathrm{~kJ} / \mathrm{mol}$ are consistent with 
electrostatic interaction between sorption sites and the metal ion (physical adsorption), while $\Delta \mathrm{G}^{\circ}$ values more negative than $-40 \mathrm{~kJ} / \mathrm{mol}$ involve charge sharing or transfer from the surface to the metal ion to form a coordinate bond (chemical adsorption). The $\Delta \mathrm{G}^{\circ}$ values obtained in this study for $\mathrm{Ni}$ (II) ions are $<-10 \mathrm{~kJ} / \mathrm{mol}$, which indicates that physical adsorption was the predominant mechanism in the sorption process (Horsfall et al., 2004). The positive value of $\mathrm{N}^{\circ}$ suggests the endothermic nature of adsorption. The positive value of $\Delta \mathrm{S}^{\circ}$ shows the increased randomness at the solid/solution interface during the adsorption process. Table (4) summarizes the values of these thermodynamic properties.

Table 4. Thermodynamic parameters for different concentrations of $\mathrm{Ni}^{2+}$ ions onto bentonite.

\begin{tabular}{|c|c|c|c|c|c|c|c|}
\hline \multirow{2}{*}{ Adsorbent } & \multirow{2}{*}{$\mathrm{C}_{0}(\mathrm{mg} / \mathrm{L})$} & \multirow{2}{*}{$\Delta \mathbf{H}^{\circ}\left(\mathbf{k j ~ m o l}^{-1}\right)$} & \multirow{2}{*}{$\Delta S^{\circ}\left(\mathbf{j ~ m o l}{ }^{-1} K^{-1}\right)$} & \multicolumn{4}{|c|}{$\Delta G^{\circ}\left(\mathrm{kj} \mathrm{mol}^{-1}\right)$} \\
\hline & & & & $25^{\circ} \mathrm{C}$ & $30^{\circ} \mathrm{C}$ & $35^{\circ} \mathrm{C}$ & $40^{\circ} \mathrm{C}$ \\
\hline \multirow{5}{*}{ Bentonite } & 50 & 36 & 125 & -1.3 & -1.9 & -2.5 & -3.2 \\
\hline & 100 & 40 & 136 & -0.6 & -1.2 & -1.9 & -2.6 \\
\hline & 200 & 37 & 124 & -0.2 & -0.4 & -1.1 & -1.6 \\
\hline & 300 & 25 & 92 & -0.1 & -0.2 & -0.5 & -1.0 \\
\hline & 400 & 14 & 46 & -0.3 & -0.4 & -0.7 & -1.0 \\
\hline
\end{tabular}

\section{Conclusion}

This paper demonstrated the efficiency in the removal of pollution agents such as $\mathrm{Ni}$ from effluents through an adsorption process. The cost of this method is relatively low when it is compared to other alternative adsorbents.

Some Nickel compounds such as Carbonyls are Carcinogenic and easily absorbed by skin.

$\mathrm{Ni}$ (11) ions from wastewater were carried out by absorption onto betonies. Studying the effect of contact time and $\mathrm{pH} \& \mathrm{~T}$ absorbent dose on the adsorption of $\mathrm{Ni}^{+2}$ ions was carried out in this study. Removal \% of Ni (II) increase when the initial concentration of benthonic. Bentonite is found to be more effective for the removal of $\mathrm{Ni}$ (II) at certain experimental conditions.

\section{References}

[1] R. C. S. S. Sect, A, Johan, C. E. S. Teo, S. L. Gan, K. H. L. Chest, Inhalational nickel carbonyl poisoning in waste processing workers, ProQuest Med. Lib. (2005)424.

[2] V. R. Ouhadi, R. N. Yong, M. Sedighi, Desorption response and degradation of buffering capability of bentonite, subjected to heavy metalcontaminants, Eng. Geol. 85(1-2) (2006) 102110.

[3] T. Novakovic, L. Rozic, S. Petrovic, A. Rosic, Synthesis and characterization of acid-activated Serbian smectite clays obtained by statistically designed experiments, Chem. Eng. 137(2) (2008) 436-442.
[4] P. Stathi, K. Litina, D. Gournis, T. S. Giannopoulos, Y. Deligiannakis, Physico-chemical study of novel organoclays as heavy metal ion adsorbents for environmental remediacion, J. Colloid Interface Sci. 316(2) (2007) 298-309.

[5] KG. Bhattacharyya, S. S. Gupta, Adsorption of a few heavy metals on natural and modified kaolinite and montmorillonite: a review, Adv. Colloid Interface 140 (2) (2008) 114-131.

[6] S. M. I. Sajidu, I. Persson, W. R. I. Masamba, E. M. T. Henry, Mechanisms of heavy metal sorption on alkaline clays from Tundulu in Malawi as determined by EXAFS, J. Hazard. Mater. 158(2-3) (2008) 401-409.

[7] W. J. Chen, L. C.. Hsiao, K. K. Y. Chen, Metal desorption from copper (II)/nickel(II)spiked kaolin as a soil component using plant-derived saponinbiosurfactant, Process Biochem. 43(5) (2008)488-498.

[8] Beliles, The lesser metals in F. W. Oehme (Ed) 1979. Toxicity of Heavy Metals in Enviroment part 2, Marcel Dekker, New York, p. 383.

[9] J. D. Dean, f. 1. Bosqui and K. H. Lanouette, Removing heavy metals from wastwater, Environ. Sci. Technol. 6, 518 (1972).

[10] H. M. F. freunglich, Uber die adsorption in Laosungen, J. ofphysical chemistry 57, 385 (1906).

[11] L. Langmiur, The constitution and fundamental properties of solid and liquid, J. of Amer. Chem. Soc. 38, 2221 (1916).

[12] M. Horsfalk, A. J. Spiff and A. A. Abia, Bull korean Chem. Soc. 25, 964 (2000). 